\section{Characterization and Performance of 16 New Inbred Lines of Lettuce}

\author{
Ivan Simko ${ }^{4}$, Ryan J. Hayes, Carolee T. Bull, and Beiquan Mou \\ U.S. Department of Agriculture, Agricultural Research Service, U.S. \\ Agricultural Research Station, 1636 E. Alisal Street, Salinas, CA 93905
}

\section{Yaguang Luo}

U.S. Department of Agriculture, Agricultural Research Service, Food Quality Laboratory, Henry A. Wallace Beltsville Agricultural Research Center, Building 002, 10300 Baltimore Avenue, Beltsville, MD 20705

\section{Mark A. Trent ${ }^{1}$, Amy J. Atallah, Edward J. Ryder², and Rebecca G. Sideman ${ }^{3}$}

U.S. Department of Agriculture, Agricultural Research Service, U.S. Agricultural Research Station, 1636 E. Alisal Street, Salinas, CA 93905

Additional index words. breeding, disease resistance, genetics, Lactuca sativa, postharvest quality, production, vegetable market

Lettuce (Lactuca sativa L.) is the most popular, commercially produced, leafy vegetable in the world (FAOSTAT, 2013). Lettuce cultivars are divided into horticultural types based on the shape and size of the head; the shape, size, and texture of the leaves; and stem length (e.g., Simko, 2013). Three prevalent types of lettuce used in U.S. cultivation are crisphead (which includes the subtypes iceberg and Batavia), romaine, and leaf. Crisphead cultivars form a spherical head; the iceberg subtype has a large, dense head, whereas the Batavia subtype has a smaller and less dense head. Romaine cultivars form an elongated head that may or may not close on the top. Leaf-type cultivars are highly variable in terms of leaf color, shape, size, texture, leaf margin, and blistering. Leaf-type lettuces generally have leaves that are shorter than romaine and heads that do not close to cover younger leaves.

Received for publication 14 Feb. 2014. Accepted for publication 18 Mar. 2014.

This research was supported by the California Leafy Greens Research Program and the California Department of Food and Agriculture Specialty Crop Block Grant Program SCB 10008.

We thank Syngenta Seeds for seed increase of advanced breeding lines, Taylor Farms for transporting lettuce, and J. McCreight for reviewing the manuscript.

Mention of trade names or commercial products in this publication is solely for the purpose of providing specific information and does not imply recommendation or endorsement by the U.S. Department of Agriculture.

${ }^{1}$ Current address: Pacific International Marketing, 740 Airport Boulevard, Salinas, CA 93901,

${ }^{2}$ Current address: 17739 Riverbend Road, Salinas CA 93908.

${ }^{3}$ Current address: Department of Biological Sciences, University of New Hampshire, Durham, NH 03824 .

${ }^{4}$ To whom reprint requests should be addressed; e-mail Ivan.Simko@ars.usda.gov.
The USDA lettuce breeding program in Salinas, CA, was initiated in 1956 (Whitaker, 1974). The program has released a large number of highly popular cultivars, including Autumn Gold, Climax, Merit, Pacific, Salinas, Salinas 88, Sea Green, Tiber, Vanguard, Vanguard 75, Winterset, etc. (COMPOSITdb, 2013; Ryder, 1979a, 1979b, 1981, 1986, 1991; Ryder and Robinson, 1991; Ryder and Waycott, 1998; Thompson and Ryder, 1961). Most of these cultivars belong to the iceberg type, the major type of lettuce produced in the United States through 1980s (for the simplicity of description, the iceberg subtype will be called "type" in the remaining part of the article). The USDA breeding priorities, however, shifted in the 1990s as a result of the increased popularity of romaine and leaf lettuces and also as a result of a larger involvement of private seed companies in lettuce breeding. The USDA breeding program is focused mostly on development of improved iceberg, romaine, and leaf lettuce inbred lines through introgression of desirable traits from wild species, heirloom material, and unadapted germplasm. The new lines are then released into the public domain and used by private or public breeding programs directly for seed increase and sales or for development of new cultivars through additional rounds of selection or mating.

We describe here the development and performance of new iceberg (six), romaine (four), and leaf (six) breeding lines. These inbred lines were evaluated for performance and resistance in field, greenhouse, and laboratory experiments. Detailed descriptions of each line provided here will allow seed companies to assess the suitability of the material for commercial production or for further development in their breeding programs.

\section{Material and Methods}

Field experiments. Eight field experiments were conducted in Salinas, CA, in
2012 and 2013 using a randomized complete block design with three replications (Table 1). Seeds were seeded in two rows $35 \mathrm{~cm}$ apart on 102-cm wide beds (center-tocenter), at least $7 \mathrm{~m}$ in length per genotype, and thinned to the final spacing of $\approx 30 \mathrm{~cm}$ between plants within a seedline, resulting in $30+$ plants per replicate. Crop cultivation was done using standard cultural practices for the area except that fungicide treatment was not applied to allow for assessment of disease resistance. Experiments included the 16 new inbred lines, their parents (or more distant ancestors), and control cultivars. Because of limiting factors such as the availability of field space, amount of seeds, disease progress, or logistics, not all accessions were evaluated for all traits in all experiments. The following accessions of the three horticultural types were evaluated: iceberg breeding lines RH08-0111, SM13-I1, SM13-I2, SM13-I3, SM13-I4, SM13-I5, parents [Calmar, Glacier, Iceberg (Batavia subtype), La Brillante (Batavia subtype), Salinas, Salinas 88] and controls (Silverado, Tiber); romaine breeding lines RH08-0464, SM13-R1, SM13-R2, SM13-R3, parents [Balady Banha (stem type), Darkland, Parris Island Cos, PI 491224] and controls (Green Towers, Hearts Delight, Lobjoits, Triple Threat); and leaf breeding lines SM13-L1, SM13-L2, SM13-L3, SM13-L4, SM13-L5, SM13-L6, parents (Grand Rapids, Lolla Rossa) and controls (Big Red, Big Star, Red Fox, Two Star). At least 12 of the evaluated parents and controls are current cultivars in production, including cvs. Big Red, Big Star, Darkland, Green Towers, Hearts Delight, Lolla Rossa, Parris Island Cos, Red Fox, Salinas (marketed under other names), Silverado, Tiber, and Two Star.

Horticultural traits, yield, and tipburn. Horticultural traits, yield, and tipburn were evaluated at harvest maturity in the $12.5 \mathrm{SP}$ and 13.5SP experiments (Table 1). Ten plants per plot that were representative of the accession were harvested and weighed together. An average head weight was determined by dividing the total weight by 10 . These 10 heads were cut in half vertically and the number of heads with tipburn symptoms was recorded (as percentage). Five of the heads were used to measure core length, head height (iceberg and romaine), head diameter at the top and bottom (romaine), and head diameter at the midsection (iceberg). The midsection head diameter was calculated from two measurements of radii that were perpendicular to each other. An experienced evaluator visually estimated the number of harvestable heads per plot. The heads were considered harvestable if their size and shape met the commercial standard for iceberg, romaine, or leaf lettuce. The percent of harvestable heads was calculated from the total number of plants per plot. The same evaluator assessed leaf ruffling and margin undulation and savoy, firmness, and closure of iceberg heads. Leaf ruffling and undulation and head savoy and closure were evaluated on a scale from 1 to 4 , where higher values 
Table 1. List of experiments, evaluated traits, and measurement units.

\begin{tabular}{|c|c|c|c|}
\hline Expt. & Location & Planting date & Evaluations and units \\
\hline $12.5 \mathrm{FB}$ & Salinas-Field B & 2 May 2012 & Lettuce drop $(\%)$ \\
\hline $12.5 \mathrm{FC}$ & Salinas-Field C & 5 May 2012 & Verticillium wilt $(\%)$ \\
\hline $12.5 \mathrm{SP}$ & Salinas-Spence & 8 May 2012 & $\begin{array}{l}\text { Head weight }(\mathrm{g}) \text {, head height }(\mathrm{cm}) \text {, head midsection diameter for iceberg }(\mathrm{cm}) \text {, head top diameter for } \\
\text { romaine }(\mathrm{cm}) \text {, head bottom diameter for romaine }(\mathrm{cm}) \text {, core length }(\mathrm{cm}) \text {, head closure }(1 \text { to } 4 \text { scale), } \\
\text { tipburn }(\%) \text {, downy mildew }(0 \text { to } 5 \text { scale), salad decay (AUDPS), whole head decay (cAUDPS) }\end{array}$ \\
\hline 12.6FA & Salinas-Field A & 26 June 2012 & $\begin{array}{l}\text { Downy mildew ( } 0 \text { to } 5 \text { scale), leafminer stings at } 30 \mathrm{~d} \text { after planting (count), leafminer mines at } 30 \mathrm{~d} \text { after } \\
\text { planting (count), leafminer stings at harvest maturity (count), salad decay (AUDPS) }\end{array}$ \\
\hline 12.6SP & Salinas-Spence & 26 June 2012 & $\begin{array}{l}\text { Downy mildew ( } 0 \text { to } 5 \text { scale), leafminer stings at } 30 \mathrm{~d} \text { after planting (count), leafminer mines at } 30 \mathrm{~d} \text { after } \\
\text { planting (count), leafminer stings at harvest maturity (count), salad decay (AUDPS) }\end{array}$ \\
\hline $12.8 \mathrm{FB}$ & Salinas-Field B & 15 Aug. 2012 & $\begin{array}{l}\text { Downy mildew ( } 0 \text { to } 5 \text { scale), lettuce drop (\%), leafminer stings at } 30 \mathrm{~d} \text { after planting (count), leafminer } \\
\text { mines at } 30 \mathrm{~d} \text { after planting (count), leafminer stings at harvest maturity (count) }\end{array}$ \\
\hline 13.5SP & Salinas-Spence & 13 May 2013 & $\begin{array}{l}\text { Head weight }(\mathrm{g}) \text {, head height }(\mathrm{cm}) \text {, head midsection diameter for iceberg }(\mathrm{cm}) \text {, head top diameter } \\
\text { for romaine }(\mathrm{cm}) \text {, core length }(\mathrm{cm}) \text {, head firmness for iceberg }(1 \text { to } 5 \text { scale }) \text {, head savoy }(1 \text { to } 4 \text { scale }) \text {, } \\
\text { number of harvestable heads }(\%) \text {, tipburn }(\%) \text {, downy mildew ( } 0 \text { to } 5 \text { scale }) \text {, salad decay (AUDPS), } \\
\text { whole head decay (cAUDPS), decay index }(0 \text { to } 1 \text { range })\end{array}$ \\
\hline $13.8 \mathrm{FB}$ & Salinas-Field B & 7 Aug. 2013 & Downy mildew (0 to 5 scale), lettuce drop (\%) \\
\hline $\mathrm{GH}$ & Greenhouse & 2013 & $\begin{array}{l}\text { Bacterial leaf spot ( } 0 \text { to } 3 \text { scale, transformed to } 0 \text { to } 1 \text { scale through integrated rating where } 0 \text { was given } \\
\text { to the most resistant accession from all horticultural types and the value of } 1 \text { was given to the most } \\
\text { susceptible one) }\end{array}$ \\
\hline Laboratory & Laboratory & 2013 & Dieback (detection of resistant $\left[\mathrm{R}_{1}, \mathrm{R}_{2}\right]$ or susceptible $\left[\mathrm{S}_{1}\right]$ haplotypes with molecular markers) \\
\hline
\end{tabular}
AUDPS = area under the disease progress stairs approach; cAUDPS = complementary area under the disease (deterioration in this analysis) progress stairs approach.

indicated more pronounced characteristics. Head firmness was evaluated on a scale from 1 to $5(1=$ no heading, $2=$ closed, puffy heads, $3=$ heads that slightly yield to hand pressure, $4=$ firm heads that do not yield to hand pressure, 5 = very firm, splitting heads).

Resistance to downy mildew. Six field experiments (12.5SP, 12.6FA, 12.6SP, $12.8 \mathrm{FB}, 13.5 \mathrm{SP}$, and $13.8 \mathrm{FB}$; Table 1) became naturally infected with Bremia lactucae. The resulting downy mildew severity was evaluated at harvest maturity using a 0 to 5 rating scale, where $0=$ no lesions, $1=$ sporadic lesions with less than one lesion per plant on average, $2=$ up to two lesions per plant, $3=$ three to 10 lesions per plant, $4=$ more than 10 lesions per plant, and $5=$ severe plant infection and merging of lesions (Simko et al., 2013). Field experiments did not include accessions with resistance based on functional $R$-gene(s), because our breeding program focuses on development of breeding lines with quantitative resistance to the disease (Simko, 2013; Simko et al., 2013).

Resistance to leafminer. Damage from leafminers (Liriomyza sp.) resulting from natural infestations was evaluated in experiments 12.6FA, 12.6SP, and 12.8FB (Table 1). The total number of leafminer mines was counted on two randomly selected plants from each plot at the baby leaf stage $(\approx 30 \mathrm{~d}$ after planting). Leafminer stings were evaluated at the baby leaf stage and at harvest maturity. Stings within the $20-\mathrm{cm}^{2}$ area of the leaf with the highest sting density were counted for each plant per plot (Mou and Liu, 2003) and averaged.

Resistance to lettuce drop. Spring (12.5FB) and fall field experiments (12.8FB and $13.8 \mathrm{FB}$ ) were conducted to evaluate resistance to lettuce drop caused by Sclerotinia minor (Table 1). Plots were infested with sclerotia of $S$. minor in the spring of 2012 and again in the spring of 2013 as described by Hayes et al. (2010). For the 12.5FB experiment, sclerotia were applied immediately before planting, whereas $12.8 \mathrm{FB}$ and $13.8 \mathrm{FB}$ experiments assessed disease resistance in soil that was infested with sclerotia produced from the previous crop. The percentage of plants that died from or exhibited lettuce drop symptoms by market maturity of the iceberg cultivars was recorded for each experiment.

Resistance to Verticillium wilt. Iceberg, romaine, and leaf lettuces were evaluated for resistance to Verticillium dahliae (race $1)$ in a $V$. dahliae-infested field $(12.5 \mathrm{FC})$ according to methods of Hayes et al. (2007) (Table 1). At market maturity 10 plants from each plot were uprooted. Disease incidence was assessed by cutting taproots longitudinally and recording the number of plants exhibiting any amount of discoloration of root vascular tissues typical of Verticillium wilt.

Postharvest decay of fresh-cut lettuce. Lettuce grown in experiments 12.5SP, 12.6FA, 12.6SP, and 13.5SP was used in evaluation of decay after processing (Table 1). Three heads (or more if heads were small) from each plot were harvested from each of three replications and placed in a $4{ }^{\circ} \mathrm{C}$ cold storage room for $1 \mathrm{~d}$ before processing. All the lettuce heads within an accession were bulked and processed into cut lettuce using the method of Hayes and Liu (2008). Nine bags per accession were produced, triple-flushed with $\mathrm{N}_{2}$ gas, sealed, and stored at $4{ }^{\circ} \mathrm{C}$. Each of the $22.8 \times 30.5-\mathrm{cm}$ transparent bags contained $340 \mathrm{~g}$ of tissue cut into $2.5-\mathrm{cm}^{2}$ pieces. Decay was visually evaluated in weekly intervals on a 0 to 10 scale that corresponds to the estimated percentage of decayed tissue divided by 10 (Simko et al., 2012). The experiment was ended 4 weeks after processing and individual ratings were combined into an overall score by the area under the disease (deterioration in this analysis) progress stairs approach (AUDPS) (Simko et al., 2012; Simko and Piepho, 2012).

Postharvest decay of whole heads. Lettuce heads were harvested from 12.5SP and 13.5SP experiments for evaluation of whole-head shelf life. Romaine and leaf types were harvested at peak maturity of 'Green Towers', whereas iceberg types were harvested at peak maturity of 'Salinas'. Equal numbers of heads from each replicate were pooled into a single carton, resulting in one carton per breeding line or cultivar. Cartons were cooled to $5{ }^{\circ} \mathrm{C}$ and shipped to Maryland through a refrigerated shipping truck provided by Taylor Farms (Salinas, CA). On arrival, the products were immediately transferred to the USDA-ARS Food Quality Laboratory in Beltsville, $\mathrm{MD}$, and stored at $5^{\circ} \mathrm{C}$. Lettuce head quality was evaluated for each accession at Day 0 (arrival quality), Day 7 . Day 14, and for romaine and leaf accessions also at Day 17. After this period all the material was considered unacceptable for sale. Product quality was evaluated by at least three trained evaluators. Overall quality was assessed following a modified procedure from Loaiza and Cantwell (1997) using a 9point hedonic scale where $9=$ like extremely; $7=$ like moderately; $5=$ neither like nor dislike; 3 = dislike moderately; and $1=$ dislike extremely (Meilgaard et al., 1991). Scores from weekly evaluations were combined into an overall rating using the AUDPS approach (Simko and Piepho, 2012). The AUDPS scores were then converted into a complementary scale (cAUDPS) by subtracting actual AUDPS scores from the maximum possible AUDPS $_{\text {Max }}$ scores (rating of 9 at all days) for the test: cAUDPS $=$ AUDPS $_{\text {Max }}$ AUDPS. This conversion was performed to keep the scale consistent with scales for other traits (e.g., resistance to diseases, tipburn, decays of fresh-cut lettuce, decay index) where higher values are less desirable.

Decay index was evaluated on the final day when the majority of lettuce heads had some amount of decay. Lettuce heads for each accession were cut in half and scores ( 0 to 4$)$ were assigned based on the decayed areas: $0=$ no decay; $1=$ decayed area less than $25 \%$ of lettuce head; $2=$ decayed area ranging from $25 \%$ to $50 \% ; 3=$ decayed area ranging from $50 \%$ to $75 \% ; 4=$ decayed 


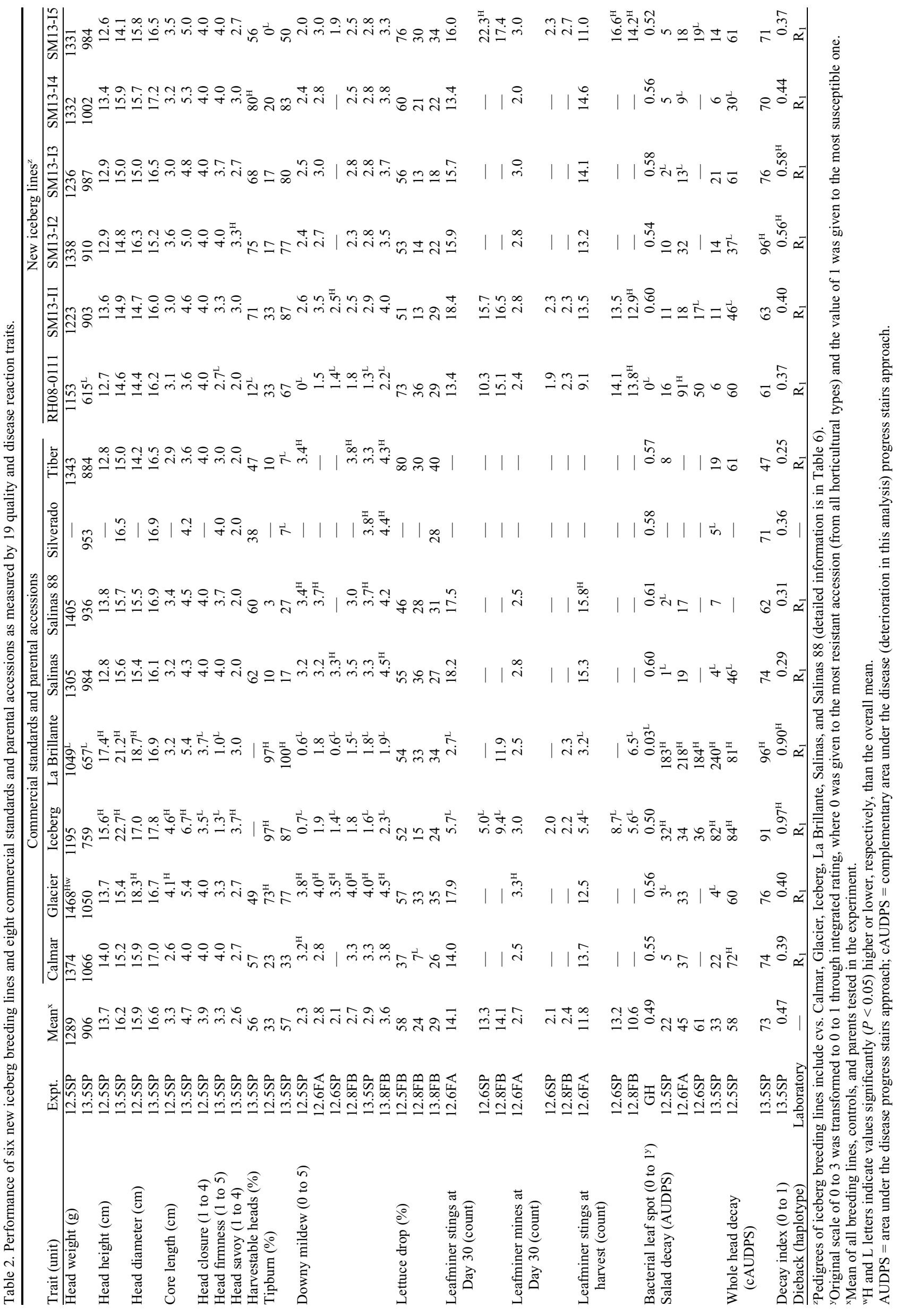




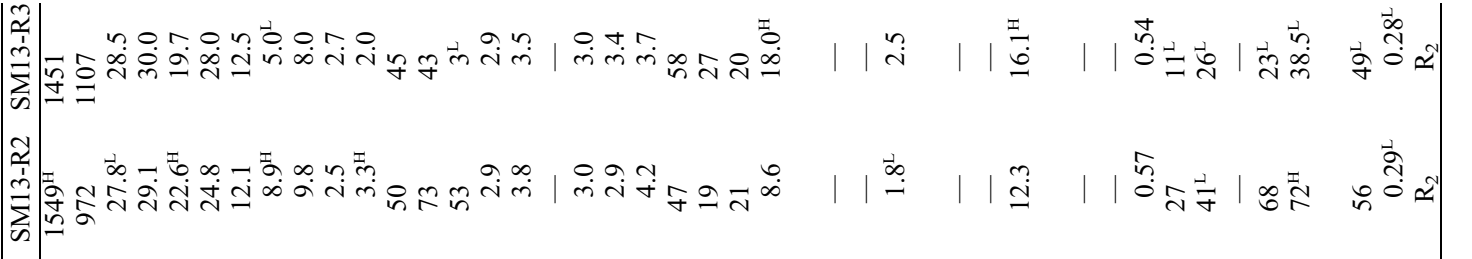

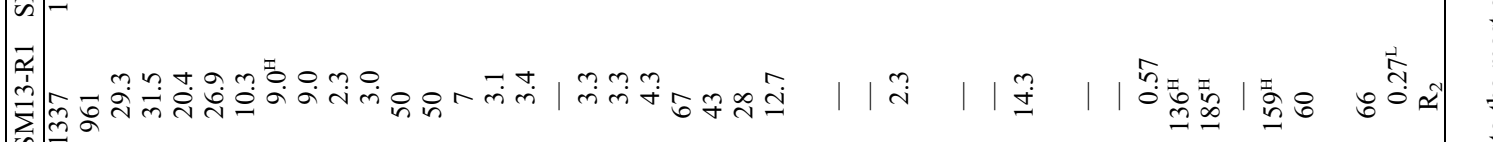

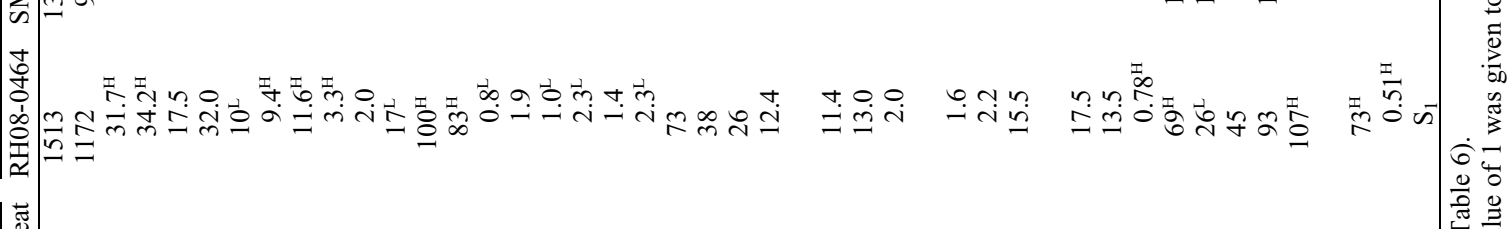

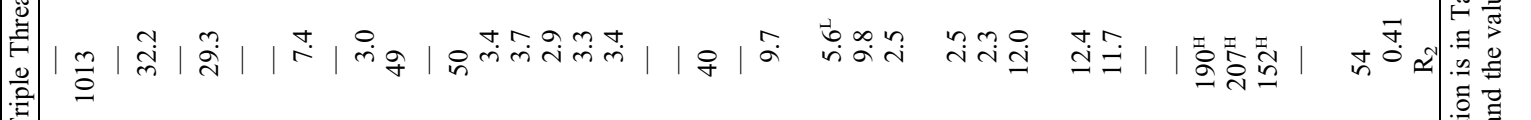

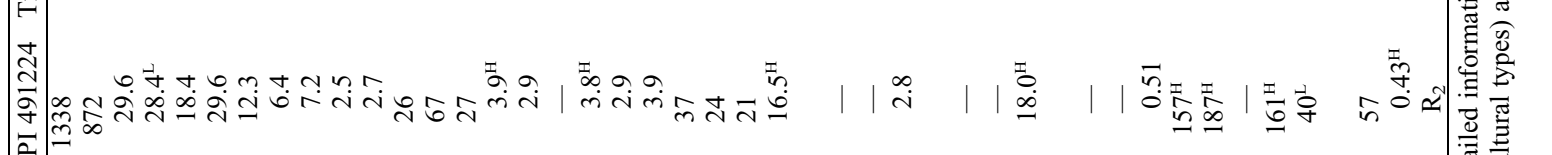

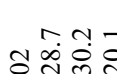

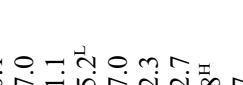

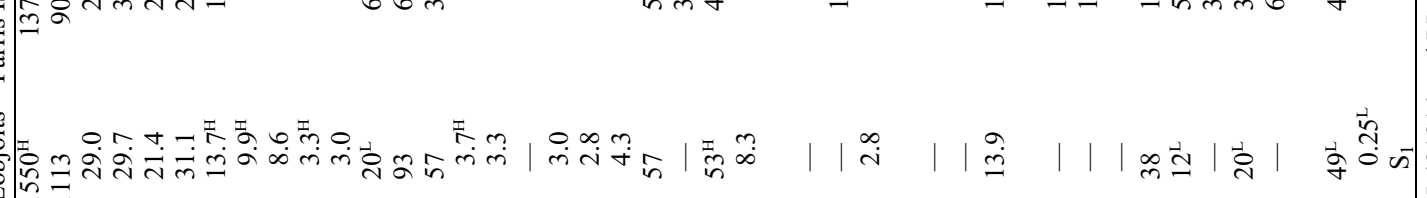

药

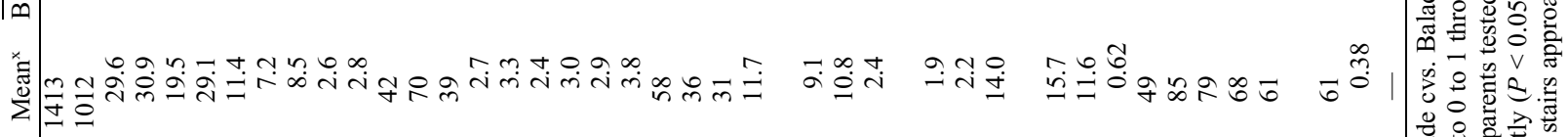

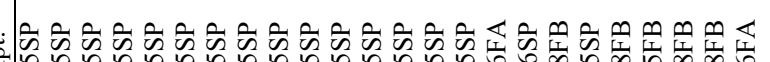

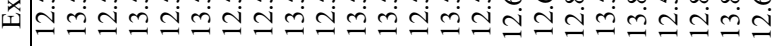

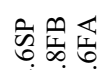

कิ İさ

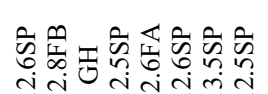

会莡

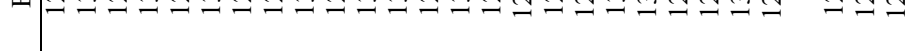




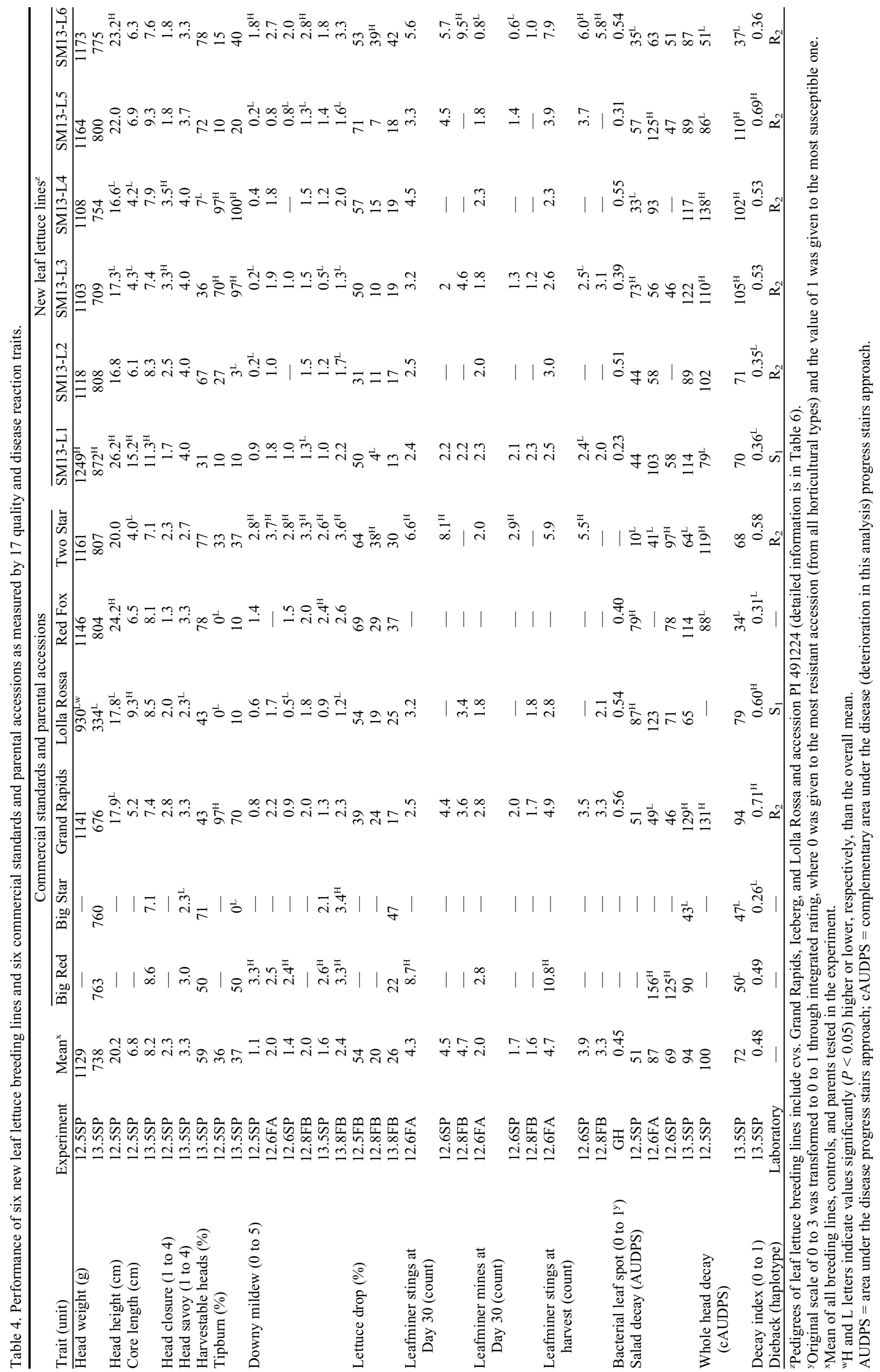


area greater than $75 \%$. Decay indices were calculated according to the formula: $D I=(0 \times$ $\left.\mathrm{N}_{0}+1 \times \mathrm{N}_{1}+2 \times \mathrm{N}_{2}+3 \times \mathrm{N}_{3}+4 \times \mathrm{N}_{4}\right) \div$ $\left(4 \times \mathrm{N}_{\mathrm{T}}\right)$, where $\mathrm{N}_{0}$ to $\mathrm{N}_{4}$ are the quantities of lettuce heads assigned each respective score and $\mathrm{N}_{\mathrm{T}}$ is the total number of lettuce heads examined for the accession.

Resistance to bacterial leaf spot. Evaluations of seedlings for resistance to bacterial leaf spot caused by Xanthomonas campestris pv. vitians $(X c v)$ were conducted using a greenhouse assay that provides data that are closely correlated with results in field experiments (Bull et al., 2007; Hayes et al., 2008, 2014). Seeds were planted in plug trays (22 $\mathrm{cm}$ wide and $65 \mathrm{~cm}$ long) with 31 rows of 11 cells that are $20 \mathrm{~mm} \times 20 \mathrm{~mm} \times 60 \mathrm{~mm}$ representing a final plant density of $\approx 2380$ plants $/ \mathrm{m}^{2}$. Plots consisted of a single row of nine plants with the perimeter of each plug tray planted with the susceptible cv. Vista Verde. In the first of three experiments, three $X c v$ strains (BS339, BS340, and BS347) were used as inoculum; however, after determining that strain BS347 was more virulent than the other strains (data not shown), only BS347 was used in the second and third experiments. All of these strains were isolated from lettuce plants in California (Barak and Gilbertson, 2003; Bull and Koike, 2005). $X c v$ suspensions of $\approx 1 \times 10^{8}$ colony-forming units $/ \mathrm{mL}$ were prepared according to Bull et al. (2007). The suspensions of each isolate were then mixed in equal proportions or the single isolate was used as prepared. Seedlings were sprayed to runoff with the $X c v$ suspension and incubated under constant leaf wetness for $7 \mathrm{~d}$. Plants were rated for disease severity using a 0 to 3 rating scale $(0=$ no disease; 1 = few lesions less than $3 \mathrm{~mm} ; 2=$ lesions greater than $3 \mathrm{~mm} ; 3=$ coalesced lesions). Disease severity values were averaged across all plants within each treatment replicate. Data from multiple experiments were combined into an overall integrated rating using rank-aggregation approach (Simko et al., 2012; Simko and Piepho, 2011). Integrated ratings were then linearly adjusted to a 0 to 1 scale, where the value of 0 was given to the most resistant accession from all horticultural types and the value of 1 was given to the most susceptible one.

Resistance to lettuce dieback. Lettuce dieback is caused by two soilborne viruses from the family Tombusviridae: Tomato bushy stunt virus and Lettuce necrotic stunt virus. Resistance to the disease is conferred by $T v r 1$, a single dominant gene (Grube et al., 2005; Simko et al., 2009). Resistance to lettuce dieback was evaluated with molecular makers closely linked to the Tvrl gene (Simko et al., 2009). Presence of the resistance alleles in lettuce accessions was tested by high-resolution DNA melting assay according to Simko (2013).

Statistical analyses. Data from each of the three lettuce types were analyzed separately with the exception of the Verticillium wilt experiment that combined all horticultural types. Normality of data distribution was tested with Shapiro-Wilk W test implemented in JMP 9.0.0 software (SAS Institute, Cary, NC). Traits with normally distributed data were analyzed using analysis of means (ANOM). Traits with non-normally distributed data or ratings performed on ordinal scales were analyzed with ANOM for ranks (JMP 9.0.0 software). The $P$ value to identify accessions significantly different from the overall mean was set at 0.05 . Integrated ratings from ranked data were calculated with Winsteps 3.65.0 (Winsteps.com, Beaverton, OR) according to Simko and Linacre (2010).

\section{Results and Discussion}

Five iceberg lines (SM13-I1 to SM13-I5) formed heads of acceptable quality with weight, height, diameter, core lengths, and firmness similar to the overall mean and control cultivars that represent industry standard (Table 2). The percentage of harvestable heads for these five lines was also acceptable with SM13-I4 having a significantly higher percentage of harvestable heads per area than the overall mean. Tipburn incidence was generally higher in the breeding lines compared with the tipburn-resistant control cvs. Silverado and Tiber; however, SM13-I5 showed no tipburn in 12.5SP. Resistance of SM13-I1 through SM13-I5 to downy mildew was usually better than in the established iceberg cvs. Glacier, Salinas, Salinas 88, Silverado, and Tiber, the favorable alleles probably originating from the highly resistant $\mathrm{cv}$. Iceberg. Resistance to other diseases and pests (lettuce drop, bacterial leaf spot, and leafminer) was similar to the iceberg control cultivars. Decay of fresh-cut lettuce and whole head decay was similar to cv. Salinas with the exception of SM13-I2 and SM13-I3, in which more rapid (but still acceptable) decay was observed on whole heads. RH080111 formed smaller and less firm heads than established cultivars or other breeding lines; thus, the percentage of harvestable heads was significantly smaller for this line. However, RH08-0111 had significantly higher resistance to downy mildew and bacterial leaf spot compared with the overall averages. Alleles for the higher resistance to these diseases in this breeding line likely originate from Batavia cv. La Brillante. All iceberg breeding lines possessed the $R_{I}$-haplotype alleles indicating a complete resistance to lettuce dieback.

Three romaine breeding lines (SM13-R1 to SM13-R3) had heads of average size and yield (Table 3). SM13-R3 had significantly lower tipburn incidence than the overall mean in one experiment (13.5SP). The remaining breeding line (RH08-0464) formed elongated heads with a long core, low percentage of harvestable heads, and high tipburn incidence. Alleles for these traits were likely inherited from cv. Balady Banha that is not used for commercial production in the United States. However, this breeding line had consistently less downy mildew than other tested romaine accessions (values were significantly different in four of six experiments). This breeding line had high susceptibility to bacterial leaf spot and more rapid decay of whole heads than was the mean of romaine accessions. These traits were likely inherited from cv. Balady Banha. RH08-0464 inherited alleles for susceptibility to dieback from cv. Darkland. The other three breeding lines had average resistance to downy mildew and bacterial leaf spot. SM13-R3 had a high number of leafminer stings but good shelf life as whole heads and fresh-cut lettuce. SM13-R1 had poor shelf life when processed for salad but acceptable shelf life of whole heads. SM13-R2 showed good resistance to leafminers and acceptable postharvest quality for whole heads and fresh-cut lettuce. All three breeding lines had the $R_{2}$-haplotype alleles inherited from accessions PI 491224 or PI 491214, indicating their complete resistance to dieback.

Table 5. Reactions of new breeding lines, commercial standards and parental accessions to Verticillium wilt race 1 .

\begin{tabular}{llc}
\hline Accession & Horticultural type & Verticillium wilt incidence (\%) \\
\hline Commercial standards and parental accessions & 27 \\
Balady Banha & Stem & 57 \\
Darkland & Romaine & 50 \\
Hearts Delight & Romaine & $0^{\mathrm{Ly}}$ \\
La Brillante & Batavia & 47 \\
Lobjoits & Romaine & $0^{\mathrm{L}}$ \\
Lolla Rossa & Leaf & 54 \\
Parris Island Cos & Romaine & 60 \\
PI 491224 & Romaine & 69 \\
Red Fox & Leaf & $83^{\mathrm{H}}$ \\
Salinas & Iceberg & 67 \\
Tiber & Iceberg & \\
New breeding lines & & $0^{\mathrm{L}}$ \\
RH08-0111 & Iceberg & $87^{\mathrm{H}}$ \\
RH08-0464 & Romaine & 57 \\
S13-R1 & Romaine & 73 \\
S13-R2 & Romaine & 43 \\
S13-R3 & Romaine & $0^{\mathrm{L}}$ \\
S13-L6 & Leaf & 46 \\
Mean & & \\
\hline
\end{tabular}

${ }^{\mathrm{z}}$ Detailed pedigree information is in Table 6 .

${ }^{\mathrm{y}} \mathrm{H}$ and L letters indicate values significantly $(P<0.05)$ higher or lower, respectively, than the overall mean. 


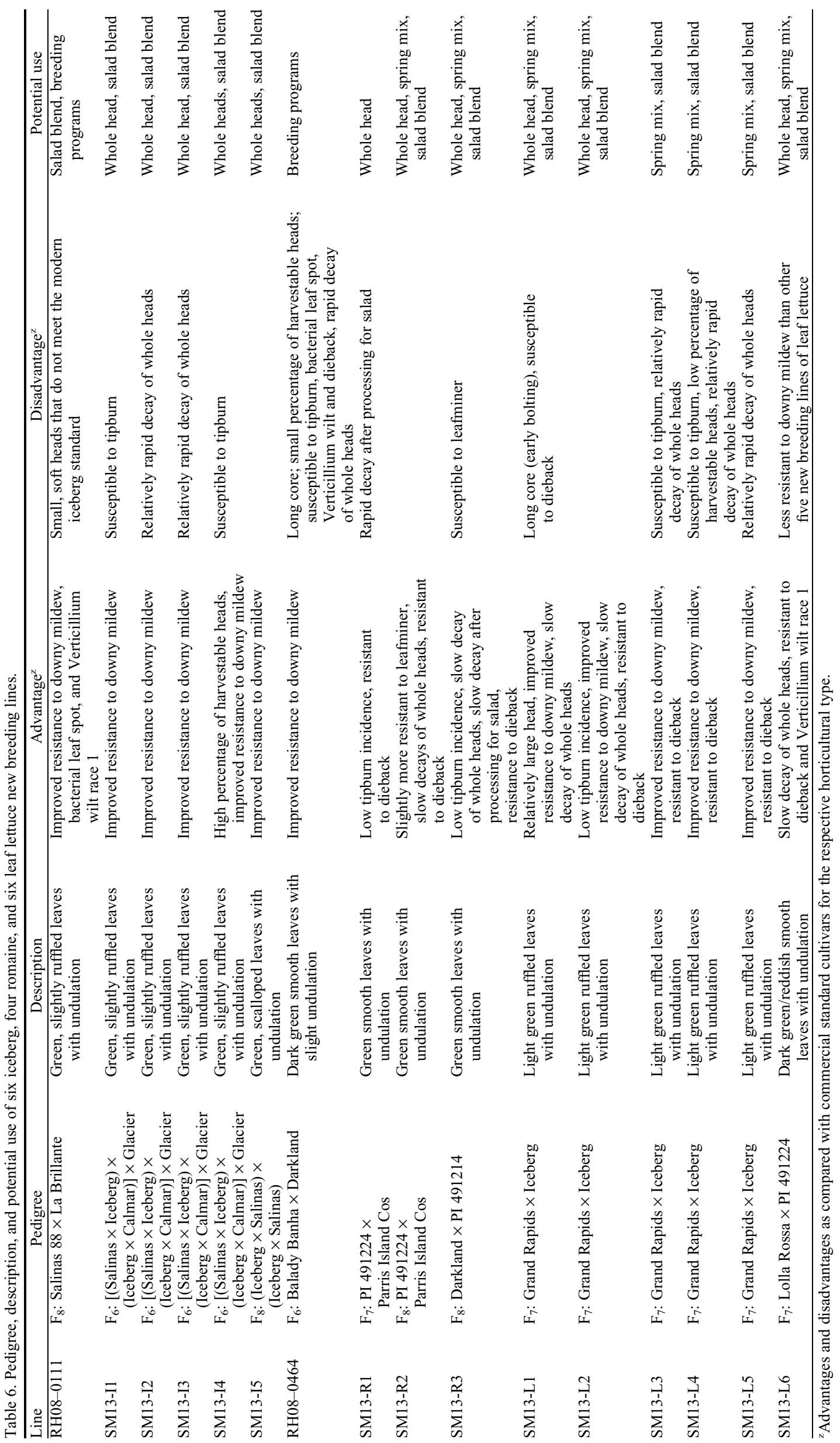


Breeding lines of leaf lettuce produced heads of acceptable size (Table 4). SM13-L1 had above average head weight accompanied by longer cores, probably as a result of earlier maturity and the initiation of bolting. SM13L2 had lower than average incidence of tipburn (in 13.5SP), whereas SM13-L4 and SM13-L5 had higher than average tipburn incidence. The low percentage of harvestable heads in SM13-L4 was caused by high tipburn incidence. Five leaf-type breeding lines (SM13-L1 to SM13-L5) had average resistance to lettuce drop, bacterial leaf spot, and leafminers. Postharvest decay after processing for salad was in the acceptable range, although it was significantly higher than the overall mean in two cases. Two of the lines (SM13-L1 and SM13L2) showed less rapid decay of whole heads, whereas two lines (SM12-L3 and SM13-L4) had decay more rapid than the average. Results for SM13-L5 were inconsistent. All five lines had average to above average resistance to downy mildew. The resistance alleles in these lines originate from both the Batavia cv. Iceberg and the leaf cv. Grand Rapids (Simko et al., 2013). The remaining breeding line (SM13L6) was relatively more susceptible to downy mildew and lettuce drop. Interestingly, this line had often a relatively high number of leafminer stings but very few leafminer mines. This may indicate presence of a limiting factor that prevents leafminer laying eggs or development of larvae. SM13-L6 had acceptable postharvest quality of whole heads and also after processing for salad. All leaf-type breeding lines, with the exception of SM13-L1, had the $R_{2}$-haplotype alleles inherited from cv. Grand Rapids and PI 491224. These alleles are associated with the complete resistance to dieback.

Testing a selected subset of accessions in a field infected with $V$. dahliae race $1(12.5 \mathrm{FC})$ identified two resistant breeding lines (Table 5). The iceberg breeding line RH08-0111 inherited $V r l$ resistance gene from cv. La Brillante (Hayes et al., 2011), whereas the leaf-type breeding line SM13-L6 inherited
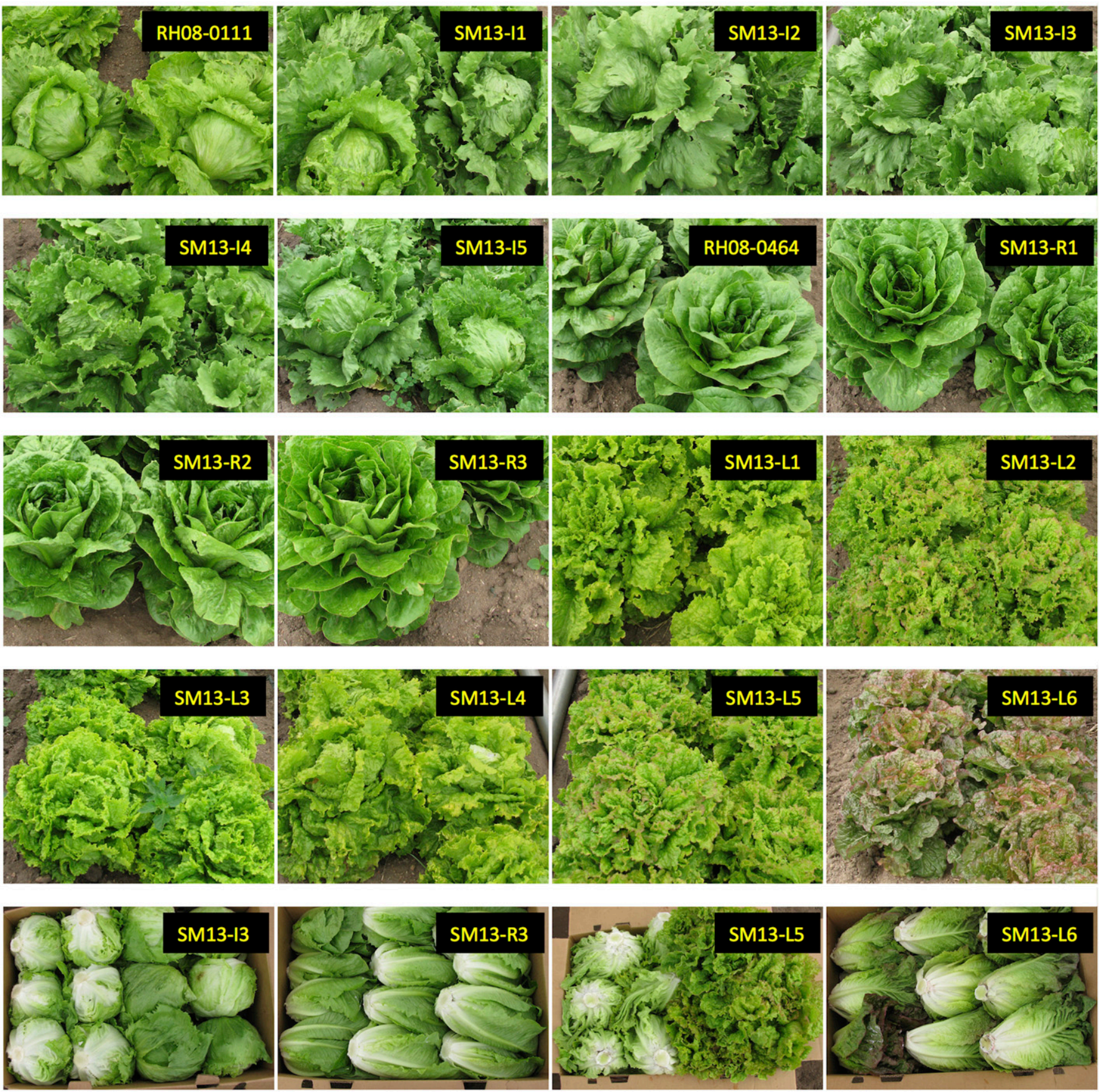

Fig. 1. Phenotypes of 16 released breeding lines from three horticultural types. The top four rows show plants growing in Expt. 12.5SP. The bottom row shows selected lines from the same experiment before shipping to Maryland for evaluations of whole head decay. 
resistance from cv. Lolla Rossa. It is unknown if the resistance in cv. Lolla Rossa is also conferred by $\mathrm{Vrl}$. Breeding lines not tested for resistance to Verticillium wilt will likely have moderate to high susceptibility to the disease, because all accessions in their pedigree are susceptible to the disease (Hayes et al., 2007; Hayes, unpublished results and present data).

The 16 new breeding lines can be used for different markets or breeding programs based on their performance. The relative performance of inbred lines (as compared with accessions of the same type), their advantages, disadvantages, and recommended use are summarized in Table 6, whereas phenotypes are shown in Figure 1. Five of six iceberg lines (SM13-I1, SM13-I2, SM13-I3, SM13-I4, SM13-I5) are suitable for salad blend and whole head markets. Although SM13-I2 and SM13-I3 exhibited more rapid decay of whole heads than the overall average, their rates of decay are expected to be acceptable for commercial production. RH08-0111 is not acceptable for commercial production of whole heads because of its small, soft heads that do not meet the standard for modern iceberg cultivars. However, the line can be used in iceberg breeding programs as a donor of alleles for resistance to downy mildew, bacterial leaf spot, and Verticillium wilt race 1 (Hayes et al., 2011). Two romaine breeding lines (SM13-R2 and SM13-R3) are suitable for salad blend, spring mix, and whole head production. Romaine breeding line SM13-R1 cannot be used for fresh-cut products, because it decays rapidly after processing, but it is suitable for the whole head market. An important trait of these three breeding lines is their resistance to dieback, because most of the currently grown romaine cultivars are susceptible to this disease (Simko et al., 2009). Romaine breeding line RH08-0464 has improved field resistance to downy mildew inherited from cv. Balady Banha. RH08-0464 can be used in breeding programs but is not suitable for commercial production. All six leaf lettuce breeding lines are acceptable for commercial production of salad blend and spring mix. SM13-L1, SM13-L2, and SM13-L6 could also be used for whole head production. SM13-L1 to SM13-L5 demonstrated very high field resistance to downy mildew with resistance alleles inherited from cvs. Iceberg and Grand Rapids. Resistance to downy mildew in these legacy cultivars appears to be durable as it was reported over 50 years ago in cv. Grand Rapids (Verhoeff, 1960) and over 90 years ago in cv. Iceberg (Milbrath, 1923). However, the lack of recent use of these cultivars in a high-intensity production environment has reduced their exposure to sustained selection for virulent races of the pathogen. Five of the leaf lettuce breeding lines (SM13L1 being the exception) have alleles for dieback resistance, a disease that may substantially limit lettuce production in California and Arizona (Simko et al., 2009). SM13-L1 is earlier bolting than other breeding lines. SM13-L6 has resistance to Verticillium wilt race 1 .

On average $\approx 99.2 \%$ of loci that were heterozygous in $\mathrm{F}_{1}$ are expected to be homozygous in $\mathrm{F}_{8}$. The value decreases to $98.4 \%$ in $\mathrm{F}_{7}$ and $96.9 \%$ in $\mathrm{F}_{6}$ generations. Therefore, there is a possibility that some of the released breeding lines may be still genetically segregating for some of the traits. No segregation is expected, however, for resistance to dieback, because only lines homozygous at Tvrl were selected for seed production through marker-assisted selection.

Limited samples of seeds are available for distribution to all interested parties for research or commercial purposes. It is requested that appropriate recognition be made if the breeding lines contribute to research or the development of new germplasm, breeding lines, or cultivars. Written requests should be sent to the first or the second author.

\section{Literature Cited}

Barak, J.D. and R.L. Gilbertson. 2003. Genetic diversity of Xanthomonas campestris pv. vitians, the causal agent of bacterial leafspot of lettuce. Phytopathology 93:596-603.

Bull, C.T., P.H. Goldman, R.J. Hayes, L.V. Madden, S.T. Koike, and E.J. Ryder. 2007. Genetic diversity of lettuce for resistance to bacterial leaf spot caused by Xanthomonas campestris pv. vitians. Plant Health Prog. DOI: 10.1094/ PHP-2007-0917-02-RS.

Bull, C.T. and S.T. Koike. 2005. Evaluating the efficacy of commercial products for managemant of bacterial leaf spot on lettuce. Plant Health Prog. DOI: 10.1094/PHP-2005-1121-01-RS.

COMPOSITdb. 2013. Lettuce cultivar database. 10 Dec. 2013. <http://compositdb.ucdavis.edu/ database/lettcv2/display>.

FAOSTAT. 2013. Crops data for 2011. 21 Feb. 2013. <http://faostat3.fao.org $>$.

Grube, R.C., W.M. Wintermantel, P. Hand, R. Aburomia, D.A.C. Pink, and E.J. Ryder. 2005. Genetic analysis and mapping of resistance to lettuce dieback: A soilborne disease caused by tombusviruses. Theor. Appl. Genet. 110:259268.

Hayes, R., E. Ryder, and C. Bull. 2008. Notice of release of six F6:8 and one F4:5 iceberg breeding lines of lettuce germplasm with resistance to bacterial leaf spot caused by Xanthomonas campestris pv. vitians. $11 \mathrm{Feb} .2014 .<\mathrm{http}: / /$ calgreens.org/control/uploads/2008_Hayes_ Ryder_and_Bull_BLSR_release_notice.pdf $>$.

Hayes, R.J. and Y.B. Liu. 2008. Genetic variation for shelf-life of salad-cut lettuce in modifiedatmosphere environments. J. Amer. Soc. Hort. Sci. 133:228-233

Hayes, R.J., L.K. McHale, G.E. Vallad, M.J. Truco, R.W. Michelmore, S.J. Klosterman, K. Maruthachalam, and K.V. Subbarao. 2011. The inheritance of resistance to Verticillium wilt caused by race 1 isolates of Verticillium dahliae in the lettuce cultivar La Brillante. Theor. Appl. Genet. 123:509-517.

Hayes, R.J., M.A. Trent, B. Mou, I. Simko, S.J. Gebben, and C.T. Bull. 2014. Baby leaf lettuce germplasm enhancement: Developing diverse populations with resistance to bacterial leaf spot caused by Xanthomonas campestris pv. vitians. HortScience 49:18-24.
Hayes, R.J., G.E. Vallad, Q.M. Qin, R.C. Grube, and K.V. Subbarao. 2007. Variation for resistance to Verticillium wilt in lettuce (Lactuca sativa L.). Plant Dis. 91:439-445.

Hayes, R.J., B.M. Wu, B.M. Pryor, P. Chitrampalam, and K.V. Subbarao. 2010. Assessment of resistance in lettuce (Lactuca sativa $\mathrm{L}$.) to mycelial and ascospore infection by Sclerotinia minor Jagger and S. sclerotiorum (Lib.) de Bary. HortScience 45:333-341.

Loaiza, J. and M. Cantwell. 1997. Postharvest physiology and quality of cilantro (Coriandrum sativum L.). HortScience 32:104-107.

Meilgaard, M., G. Civille, and B. Carr. 1991. Sensory evaluation techniques. CRC Press, Boca Raton, FL.

Milbrath, D.G. 1923. Downy mildew of lettuce in California. J. Agric. Res. 23:689-696.

Mou, B. and Y.-B. Liu. 2003. Leafminer resistance in lettuce. HortScience 38:570-572.

Ryder, E. 1979a. 'Salinas' lettuce. HortScience 14:283-284.

Ryder, E. 1979b. 'Vanguard 75' lettuce. HortScience 14:284-286.

Ryder, E. 1981. 'Sea Green' lettuce. HortScience 16:571-572.

Ryder, E. 1986. 'Winterset' lettuce. HortScience 21:1464-1465.

Ryder, E.J. 1991. 'Salinas 88' lettuce. HortScience 26:439-440.

Ryder, E.J. and B.J. Robinson. 1991. 'Pacific' lettuce. HortScience 26:437-438.

Ryder, E.J. and W. Waycott. 1998. Crisphead lettuce resistant to tipburn: Cultivar Tiber and eight breeding lines. HortScience 33:903-904.

Simko, I. 2013. Marker-assisted selection for disease resistance in lettuce. In: Varshney, R.K. and R. Tuberosa (eds.). Translational genomics for crop breeding. Volume I: Biotic stresses. Wiley, Hoboken, NJ.

Simko, I., A.J. Atallah, O.E. Ochoa, R. Antonise, C.H. Galeano, M.J. Truco, and R.W. Michelmore. 2013. Identification of QTLs conferring resistance to downy mildew in legacy cultivars of lettuce. Sci. Rep. 3:2875.

Simko, I., R.J. Hayes, and M. Kramer. 2012. Computing integrated ratings from heterogeneous phenotypic assessments: A case study of lettuce post-harvest quality and downy mildew resistance. Crop Sci. 52:2131-2142.

Simko, I. and J.M. Linacre. 2010. Combining partially ranked data in plant breeding and biology: II. analysis with Rasch model. Commun. Biom. Crop Sci. 5:56-65.

Simko, I., D.A. Pechenick, L.K. McHale, M.J. Truco, O.E. Ochoa, R.W. Michelmore, and B.E. Scheffler. 2009. Association mapping and marker-assisted selection of the lettuce dieback resistance gene Tvr1. BMC Plant Biol. 9.

Simko, I. and H.P. Piepho. 2011. Combining phenotypic data from ordinal rating scales in multiple plant experiments. Trends Plant Sci. 16:235-237.

Simko, I. and H.P. Piepho. 2012. The area under the disease progress stairs (AUDPS): Calculation, advantage, and application. Phytopathology 102:381-389.

Thompson, R.C. and E.J. Ryder. 1961. Descriptions and pedigrees of nine varieties of lettuce. U.S. Dept. of Agriculture Technical Bulletin No. 1244.

Verhoeff, K. 1960. On the parasitism of Bremia lactucae Regel on lettuce. Tijdschr. Pl. Ziekt. 66:133-203.

Whitaker, T.W. 1974. Lettuce: Evolution of a weedy Cinderalla. HortScience 9:512-514. 